\title{
High-affinity $\mathbf{T}$ cell receptors redirect cytokine-activated $\mathbf{T}$ cells (CAT) to kill cancer cells
}

\author{
Synat Kang ${ }^{1,2}$, Yanyan $\mathrm{Li}^{1}$, Yifeng $\mathrm{Bao}^{1}$, Yi Li $(\bowtie)^{1,2}$ \\ ${ }^{1}$ State Key Laboratory of Respiratory Disease, Guangzhou Institutes of Biomedicine and Health, Chinese Academy of Sciences, Guangzhou \\ 510530, China; ${ }^{2}$ University of Chinese Academy of Sciences, Beijing 100049, China
}

(C) The Author(s) 2019. This article is published with open access at link.springer.com and journal.hep.com.cn

\begin{abstract}
Cytokine-activated $T$ cells (CATs) can be easily expanded and are widely applied to cancer immunotherapy. However, the good efficacy of CATs is rarely reported in clinical applications because CATs have no or very low antigen specificity. The low-efficacy problem can be resolved using $T$ cell antigen receptorengineered CAT (TCR-CAT). Herein, we demonstrate that NY-ESO-1 157-165 HLA-A*02:01-specific high-affinity TCR (HAT)-transduced CATs can specifically kill cancer cells with good efficacy. With low micromolar range dissociation equilibrium constants, HAT-transduced CATs showed good specificity with no off-target killing. Furthermore, the high-affinity TCR-CATs delivered significantly better activation and cytotoxicity than the equivalent TCR-engineered $T$ cells (TCR-Ts) in terms of interferon- $\gamma$ and granzyme $B$ production and in vitro cancer cell killing ability. TCR-CAT may be a very good alternative to the expensive TCR-T, which is considered an effective personalized cyto-immunotherapy.
\end{abstract}

Keywords cytokine-activated T cells; high-affinity T cell receptor; cancer immunotherapy; TCR-CAT

\section{Introduction}

Genetically engineered $\mathrm{T}$ cells have produced promising and exciting results for cancer immunotherapy in clinical trials [1-3]. MART-1-specific wild-type $\mathrm{T}$ cell antigen receptor (TCR)-transduced autologous $\mathrm{T}$ cells have demonstrated a noticeable clinical benefit for treating metastatic melanoma [1]. However, wild-type TCRs have low, suboptimal affinity for their target (dissociation equilibrium constant, $\left.\mathrm{K}_{\mathrm{D}}=1-100 \mu \mathrm{mol} / \mathrm{L}\right)[4,5]$ under tumor escaping conditions. T cells expressing high-affinity TCR (HAT) are eliminated during the development in the thymus for the prevention of autoimmunity [6]. However, artificially engineered HAT can enhance T cell-capturing antigens and the ability to kill target cells in vitro and in vivo [7]. HAT-transduced $\mathrm{T}$ cells (TCR-T) delivered a remarkable objective clinical response for treating myeloma $[3,8,9]$, synovial cell sarcomas, and melanoma [10] with no evidence of severe adverse events $[3,8,9]$; this treatment, however, is very expensive. Thus, ex vivo expansion of less costly cytokine-induced effector cells,

Received May 4, 2018; accepted November 16, 2018

Correspondence: Yi Li, li_yi@gibh.ac.cn which constitute a heterogeneous lymphocyte population, from peripheral blood mononuclear cells (PBMCs) with anti-CD3 monoclonal antibody (mAb) (OKT3), interluekin (IL)-2, and interferon (IFN)- $\gamma$ has been attempted $[11,12]$. Phenotypically, such a cell mixture is dominated by a large $\mathrm{CD} 8^{+} \mathrm{T}$ cell population. Therefore, we refer to these kinds of cells as cytokine-activated T cells (CATs). The cancer cell killing efficacy of these cells was positively correlated with the quantity of CAT applied in many previous investigations [13]. Obtaining a sufficient number of effector cells is a critical step in the successful application of CAT-based immunotherapy. Fortunately, CAT can be easily expanded ex vivo by over 1000 -fold after 2-3 weeks of culture [14-17].

CATs are considered the ideal cells to treat cancer [18]. Based on the ClinicalTrials.gov database (http://www. clinicaltrials.gov), the therapeutic potential of CAT has been broadly explored in clinical trials for both hematologic malignancies and solid tumors. Attractive outcomes of improved overall survival and life quality have been observed with minor side effects for patients with cancer [19]. However, the current efficacy of CAT treatment is unable to meet the needs of cancer medical care in clinical practice as these cells have minimal specificity for cancer. Thus, increasing the number of antigen-specific effector 
cells in the cell population can enhance treatment effectiveness.

Reliable antigen targets are essential for conferring CATs with antigen specificity for clinical applications. Clinical trials have been carried out with TCR-T for targeting tumor antigens, such as MART-1, CEA, gp100, NY-ESO-1, and MAGE-A3 [20]. The NY-ESO-1 antigen is an immunogenic cancer testis antigen that is expressed in many cancer cells from $10 \%-50 \%$ of metastatic melanomas, breast, prostate, thyroid, and ovarian cancers, and $80 \%$ of synovial cell sarcomas [21-24]. TCR-T therapy for the HLA*A02:01-restricted NY-ESO-1 ${ }_{157-165}$ peptide epitope has been shown to be effective and safe when it is targeted with HAT variants.

Herein, we investigated whether CATs expressing HAT can enhance the immune response against tumor cells. Specifically, we studied the activation and killing efficiency of HAT-transduced CATs with various $\mathrm{K}_{\mathrm{D}} \mathrm{s}$. CATs were transduced with the wild-type HLA-A*02:01restricted, NY-ESO- $1_{157-165}$-specific $1 \mathrm{G} 4$ TCR $\left(\mathrm{K}_{\mathrm{D}}=32\right.$ $\mu \mathrm{mol} / \mathrm{L}$ ), and four HAT variants of this TCR that bound with high affinity $\left(\mathrm{K}_{\mathrm{D}}=1.07 \mu \mathrm{mol} / \mathrm{L}, 84 \mathrm{nmol} / \mathrm{L}, 5 \mathrm{nmol} / \mathrm{L}\right.$, and $26 \mathrm{pmol} / \mathrm{L}$ ). Our results demonstrated that the optimal affinity TCR had a $\mathrm{K}_{\mathrm{D}}$ in the micromolar range, and that TCR-transduced CAT exhibited better activation and cancer cell killing than TCR-transduced T cells in parallel assays.

\section{Materials and methods}

\section{Cell lines}

The antigen NY-ESO-1 $157-165$ and HLA-A*02:01 double positive cells were the human tumor lines A375, Mel624, and U266-B1. The antigen NY-ESO- $1_{157-165}$-negative and HLA-A2 positive cells were the melanoma line Mel526 and lung carcinoma line NCI-H1650. A375, U266-B1, and NCI-H1650 were purchased from the American Type Culture Collection. Mel624 and Mel526 were gifts from Prof. Cassin Yee's laboratory. In addition, we also obtained human erythroleukemic cells (K562) transfected with HLA*A02:01 and NY-ESO-1 from Xiangxue Life Sciences Ltd. All tumor cell lines were checked with HLA typing (BFR Gene Diagnostics, Beijing, China) and mRNA expression (Nanostring, Guangzhou, China). The Mel624, U266-B1, Mel526, and NCI-H1650 cells were maintained in RPMI 1640 (GIBCO Life Technologies, Shanghai, China) supplemented with $10 \%$ fetal bovine serum (FBS) (GIBCO Life Technologies). The A375 was maintained in Dulbecco's modified Eagle medium (DMEM, GIBCO Life Technologies) supplemented with $10 \%$ FBS. The T2 cell line (human lymphoblast) was maintained in RPMI 1640 culture medium supplemented with $10 \%$ FBS. The $293 \mathrm{~T}$ cell line is a human embryonic kidney cell, which was cultured in DMEM supplemented as described previously.

\section{Lentivirus vector construction and viral production}

The high-affinity HLA-A2/NY-ESO-1-specific TCR genes (HATs), namely, $1.07 \mu \mathrm{mol} / \mathrm{L}, 84 \mathrm{nmol} / \mathrm{L}, 5 \mathrm{nmol} / \mathrm{L}$, $26 \mathrm{pmol} / \mathrm{L}$, and wild-type $32 \mu \mathrm{mol} / \mathrm{L}$ were constructed as described previously $[8,25]$. For lentiviral particle production, the desired TCR $\alpha$ and $\beta$ chain genes were cloned into a lentiviral vector pGZ178. The 293T cells were transduced with the following constructs: packaging construct (RRE), Rev Expression plasmid (REV), envelope construct (pG2M.D), and the lentiviral vector containing TCR genes. The culture medium was refreshed every 7-8 $\mathrm{h}$ after transduction, and the supernatant was collected twice and filtered through $0.45 \mu \mathrm{m}$ membranes at 48 and $72 \mathrm{~h}$. The supernatant was concentrated by ultracentrifugation $(50 \mathrm{kDa}$ centrifugal filter units; Merck kGaA, Germany) at $4000 \times g$ at $4{ }^{\circ} \mathrm{C}$ for $20 \mathrm{~min}$ and stored at $-80{ }^{\circ} \mathrm{C}$. To determine the titration of lentiviral particles, $1.5 \times 10^{4}$ Jurkat cells were seeded into each well of 96well U-bottom plates (Corning, NY, USA) with 10-fold serial dilutions ranging from $10^{-2}$ to $10^{-7}$ of the lentiviral stock and incubated for $72 \mathrm{~h}$ at $37^{\circ} \mathrm{C}$ in $5 \% \mathrm{CO}_{2}$. The TCR expression was detected by staining the cells with antihuman TCR V $\beta 13.1$ (FITC, Biolegend) or NY-ESO-1 tetramer (APC). The calculation of lentiviral titration was performed as described previously [26,27].

\section{Preparation of CAT and T cells}

Human peripheral blood was obtained from healthy donors at Guangzhou Blood Center (Guangzhou, Guangdong, China). PBMCs were isolated from buffy coats by means of Lymphoprep $^{\mathrm{TM}}$ density gradient centrifugation (Axis-Shield PoC AS, Oslo, Norway). The PBMCs used in this study were HLA-A2 ${ }^{+}$and analyzed by staining with HLA-A2 $\mathrm{mAb}$ (FITC, Biolegend). The CATs were generated as described previously [28]. Briefly, $5 \times 10^{6}$ cells $/ \mathrm{mL}$ PBMCs were cultured in AIM-V medium (supplemented with $10 \%$ heat-inactivated FBS) and $1000 \mathrm{U} / \mathrm{mL}$ IFN- $\gamma$ (PeproTech Inc., Beijing, China) for $24 \mathrm{~h}$. The cells were activated with $100 \mathrm{ng} / \mathrm{mL}$ CD3 mAb (clone OKT3; Biolegend), $50 \mu \mathrm{g} / \mathrm{mL}$ RetroNectin (TAKARA), and $500 \mathrm{U} / \mathrm{mL}$ of IL-2 (Beijing Forring Bio-Pharmaceutical, Beijing, China). Fresh medium containing IL-2 (500 U/mL) was used to replace half of the culture medium every $3 \mathrm{~d}$. Phenotypic analyses were performed weekly (Fig. 1A-a).

To prepare T cells, isolated $1 \times 10^{6} \mathrm{PBMCs}\left(\mathrm{HLA}-\mathrm{A} 2^{+}\right)$ were activated with $100 \mathrm{U} / \mathrm{mL}$ IL-2 and $200 \mathrm{ng} / \mathrm{mL}$ CD3/ CD28 mAb microbeads (GIBCO Life Technologies) according to the manufacturer's instructions. Fresh medium containing IL-2 $(100 \mathrm{U} / \mathrm{mL})$ was used to replace half of the culture medium every $3 \mathrm{~d}$ (Fig. 1A-b). 
A

a) CAT cells

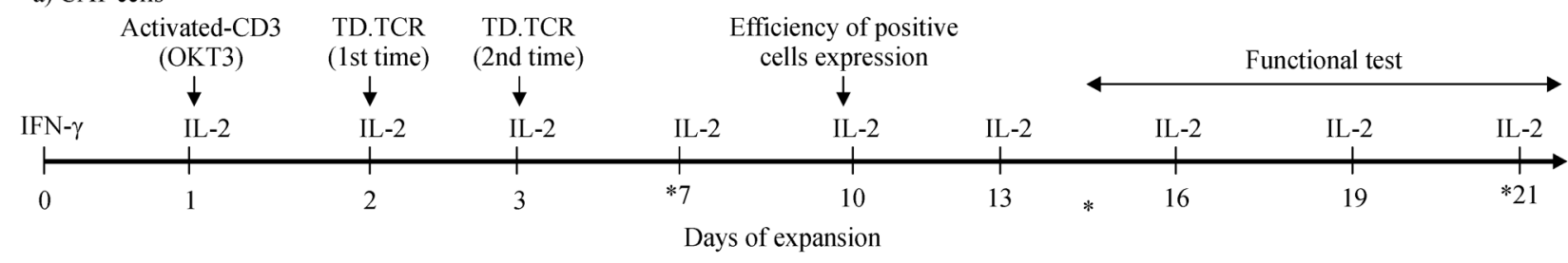

b) T cells

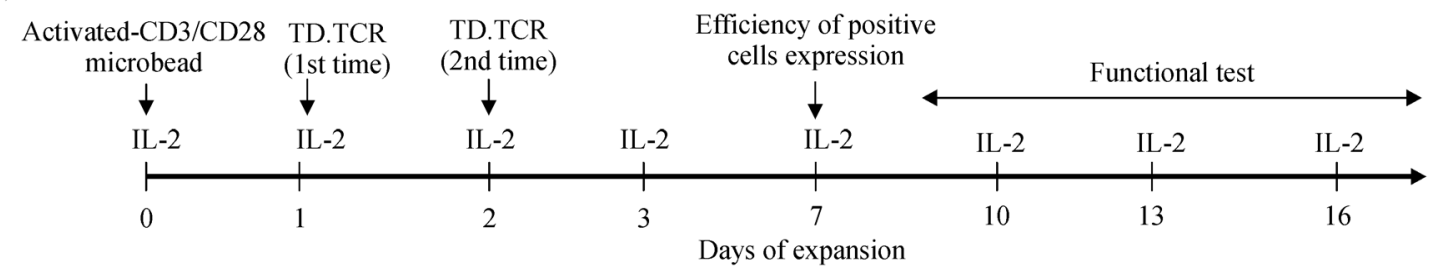

TD.TCR $=$ transduced-TCR

(*) Asterisks indicated weekly phenotypic performant of cytokine activated T cells (CAT)

B
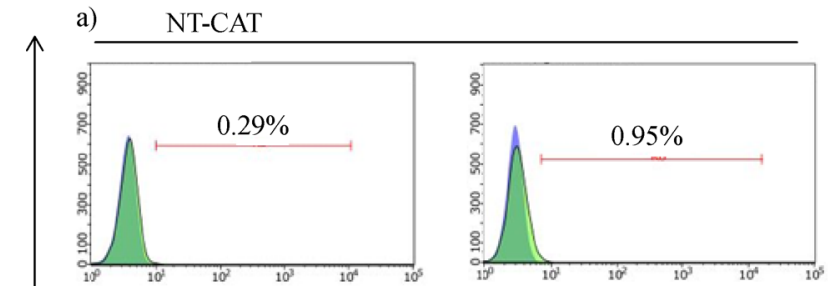

c) $\quad(1.07 \mu \mathrm{mol} / \mathrm{L}) \mathrm{TCR}-\mathrm{CAT}$
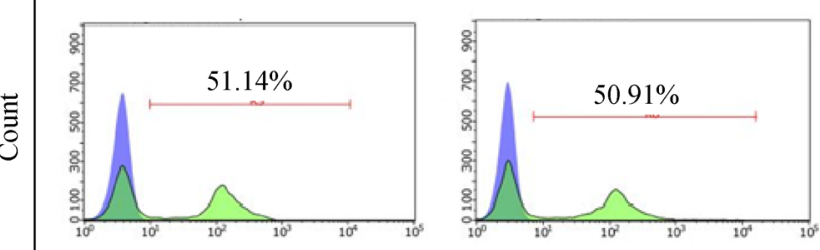

e) $\quad(5 \mathrm{nmol} / \mathrm{L}) \mathrm{TCR}-\mathrm{CAT}$
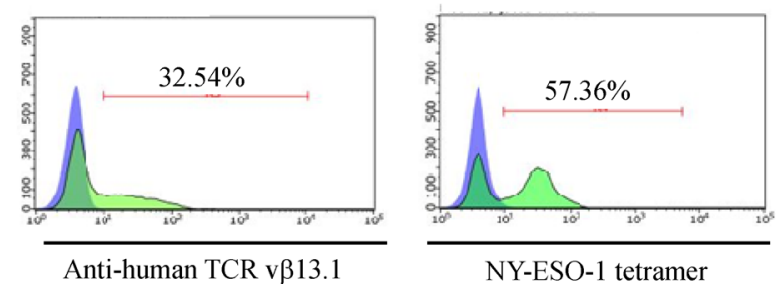

b) $\quad(32 \mu \mathrm{mol} / \mathrm{L}) \mathrm{TCR}-\mathrm{CAT}$

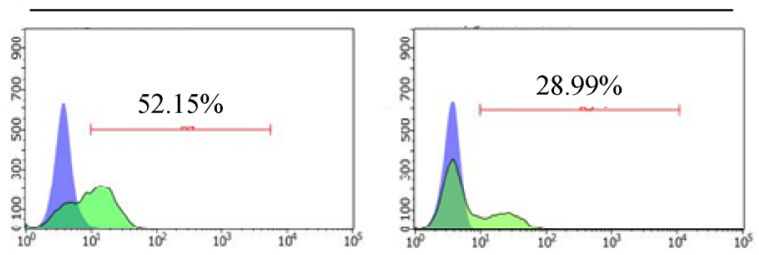

d) $\quad(84 \mathrm{nmol} / \mathrm{L}) \mathrm{TCR}-\mathrm{CAT}$
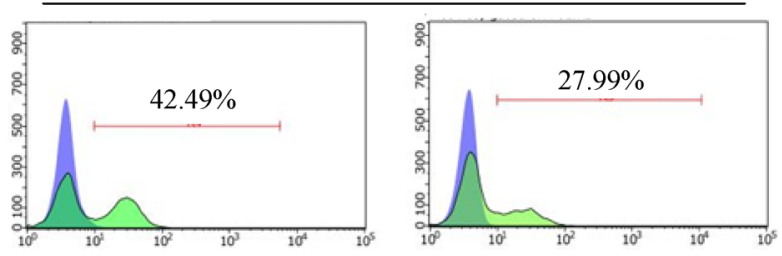

f) $(26 \mathrm{pmol} / \mathrm{L}) \mathrm{TCR}-\mathrm{CAT}$
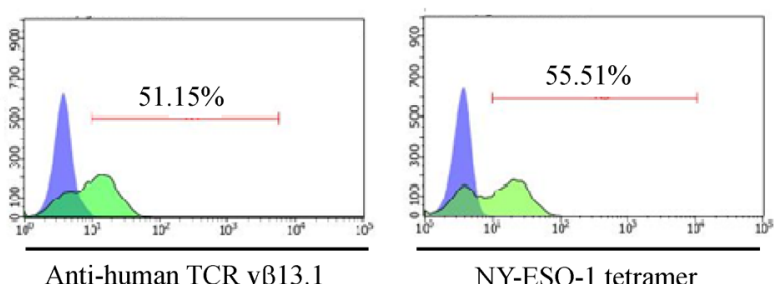

Fig. 1 Expansion of CAT or T cells and phenotypes of high-affinity TCR-transduced CAT (TCR-CAT) cells or T cells (TCR-T). (A) Time line of cell expansion, transduction, and functional test. a) CAT cells. PBMCs from consented healthy donors were initially stimulated with IFN- $\gamma$ (day 0), followed by addition of CD3 mAb (day 1). b) T cells. PBMCs from consented healthy donors were activated with CD3/CD28 microbeads. IL-2 was supplemented every $3 \mathrm{~d}$. Other details are provided in the Materials and methods section. (B) Efficiency of cell expression of 1G4 HAT in CAT cells. The expression levels of TCR in CAT cells were confirmed by flow cytometry by staining the cells with anti-human TCR v $\beta 13.1$ or NY-ESO-1 tetramer. 


\section{Generation of NY-ESO-1 specific TCR gene-trans- duced CAT and $\mathrm{T}$ cells}

For transduction of CATs with the HATs, $1 \times 10^{6}$ cells of activated CATs were transduced with lentiviral particles with a multiplicity of infection of 5 (5 MOI) in the presence of polybrene $(8 \mu \mathrm{g} / \mathrm{mL})$, and transduction was repeated once after $72 \mathrm{~h}$. The positive HAT expression on CAT was determined by staining with antihuman TCR v $\beta 13.1$ or NY-ESO-1 tetramer $3 \mathrm{~d}$ after the last lentiviral particle transduction.

To prepare TCR-T, $1 \times 10^{6}$ cells of the activated T cells were transduced with lentiviral particles as mentioned above in the TCR-CAT cell transduction. To compare the functional activities of TCR-CAT and TCR-T cells transduced with TCR-1.07 $\mu \mathrm{mol} / \mathrm{L}$, cells showing positive HAT expression of TCR-CAT and TCR-T were detected by staining with antimouse TCR $\beta$ chain (APC) (Biolegend) $3 \mathrm{~d}$ after the last lentiviral particle transduction. CAT and TCR-CATs were expanded for approximately 2-3 weeks, whereas $\mathrm{T}$ and TCR-T cells were expanded for approximately 2 weeks.

\section{Cell phenotyping by flow cytometry}

Multicolor flow cytometry gating was applied to analyze the expression of cell surface molecules. CATs were labeled with various conjugated mAbs (FITC, PE, PC7, and APC) to detect the following surface markers: CD3, CD8, CD4, and CD56 (Biolegend). Briefly, $1 \times 10^{6}$ cells were resuspended in $100 \mu \mathrm{L}$ of washing buffer (PBS $+2 \%$ FBS) and stained with the antibodies in the dark at $4{ }^{\circ} \mathrm{C}$ for $20 \mathrm{~min}$. The cells were washed twice with washing buffer before and after cell staining. The cells were analyzed with Guava easyCyte HT (EMD Millipore Cooperation, USA).

\section{Enzyme-linked immunospot (ELISPOT) assay}

An ELISPOT assay was performed according to the manufacturer's instructions (BD Biosciences, BioTechne). Briefly, 96-well flat-bottomed plates were precoated with primary antibodies specific for IFN- $\gamma$ or granzyme $\mathrm{B}$ at a $5 \mu \mathrm{g} / \mathrm{mL}$ concentration. The effectors were plated at a final concentration of $2 \times 10^{3}$ cells per well in duplicates in the presence of $2 \times 10^{4}$ target cells.
To detect TCR dependence and HLA restriction, TCRblocking experiments were performed as follows. Tumor target cells were pre-incubated with $20 \mu \mathrm{g} / \mathrm{mL}$ (final concentration) high-affinity soluble $1 \mathrm{G} 4 \mathrm{TCR}\left(\mathrm{K}_{\mathrm{D}}=26\right.$ $\mathrm{pmol} / \mathrm{L}$ ) for $30 \mathrm{~min}$ at room temperature. For HLA class I blocking, the experiments were performed as described previously [28]. The plate was washed with culture medium (AIM-V + 10\% FBS), and the culture medium was added as the blocking solution at room temperature for $2 \mathrm{~h}$. The plate was washed, and a biotinylated secondary antibody was added after $24 \mathrm{~h}$. The plate was incubated for $2 \mathrm{~h}$ and washed. Buffer containing streptavidin-horseradish peroxidase was added and incubated for $1 \mathrm{~h}$. After additional washes, the 3-amino-9-ethylcarbazole substrate was added, and incubation was performed at room temperature for 3-5 min (AEC Substrate Kit; SigmaAldrich). The reaction was stopped by addition of water, and the plate was air-dried and analyzed using an ELISPOT reader (AID Elispot Reader, Germany).

\section{Cytotoxicity assay}

The cytotoxicity activity of transduced high-affinity TCRCATs was assessed by CytoTox 96® Non-Radioactive Cytotoxicity Assay (Promega, Madison, USA) according to the manufacturer's instructions. The effector cells were prepared in fresh medium and cultured with a constant number of $2 \times 10^{4}$ target cells. The serial effector to target ratios $(\mathrm{E}: \mathrm{T})$ used were $5: 1,1: 1$, and $1: 2$. The effector cells and target cells were seeded into 96-well U-bottom plates (Corning, NY, USA). To study TCR dependence, tumor targets were pre-incubated with $20 \mu \mathrm{g} / \mathrm{mL}$ of the highaffinity soluble 1G4 TCR (used as mentioned above) for $30 \mathrm{~min}$ at room temperature, followed by coculture with the effectors at an E:T ratio of 5:1. Control groups were set up to measure effector molecule release and spontaneous release (only effector/target cells added), maximum release (target cells added with $20 \mu \mathrm{L} 10 \times$ lysis buffer), and medium background (no cells added). After co-incubation at $37{ }^{\circ} \mathrm{C}$ for $24 \mathrm{~h}$, culture plates were centrifuged, and $50 \mu \mathrm{L}$ of supernatant was carefully transferred into flat bottom plates, and $50 \mu \mathrm{L}$ of CytoTox $96 \AA$ reagent was added. The mixed solution was kept in the dark to protect it from light and then incubated for $30 \mathrm{~min}$ at room temperature. Killing efficacy was calculated using the following formula:

$$
\% \text { Cytotoxicity }=\frac{\text { Experimental }- \text { Effector Spontaneous }- \text { Target Spontaneous }}{\text { Target Maximum }- \text { Target Spontaneous }} \times 100
$$

\section{Assays with peptide-pulsed cells}

To study the antigen specific recognition by high-affinity TCR expression on CATs, T2 cells were pulsed with the
C9V variant of NY-ESO-1 ${ }_{157-165}$ peptide (SLLMWITQV) or an irrelevant SAGE-1 peptide VFSTVPPAFI at concentrations ranging from $10^{-6} \mathrm{~mol} / \mathrm{L}$ to $10^{-11} \mathrm{~mol} / \mathrm{L}$ for $30 \mathrm{~min}$, followed by plating out at a concentration of $2 \times 10^{4}$ cells per well with $2 \times 10^{3}$ effector cells $(\mathrm{E}: \mathrm{T}=$ 
1:10) for the ELISPOT assay and $1 \times 10^{5}$ effector cells (E: $\mathrm{T}=5: 1)$ for the lactate dehydrogenase (LDH) assay. Detection of cytokine release and cytotoxicity was performed as described above.

\section{CD107a degranulation assay}

To study the activation and degranulation of TCR-CAT, various high-affinity TCR-transduced CAT (TCR-CAT) or nontransduced CAT (NT-CAT) cells were cocultured with $2 \times 10^{4}$ target cells at an E:T ratio of 1:1 and incubated for $16 \mathrm{~h}$ at $37^{\circ} \mathrm{C}$ in $5 \% \mathrm{CO}_{2}$. Cells were washed with washing buffer solution (2\% FBS + PBS) and stained with an antilysosomal-associated membrane protein-1 (anti-CD107a)PE conjugated antibody (BD Pharmingen) and an antihuman CD3-APC conjugated antibody (Biolegend). The percentage of CD107a positive cells was electronically gated according to the light-scattering properties and analyzed with Guava easyCyte HT.

\section{IncuCyte apoptosis assay}

We performed apoptosis assay by using IncuCyte $\mathrm{ZOOM}^{\mathrm{TM}}$ (Essen BioScience, MI, USA) according to the manufacturer's instructions. Briefly, target cells were seeded at an appropriate density $\left(7 \times 10^{3}\right.$ cells/well $)$ in a 96-well plate (black, clear bottom with tissue culture treatment) (Corning, NY, USA) and incubated at $37{ }^{\circ} \mathrm{C}$ overnight. The cell plates were then incubated with the effector cells at E:T ratios of 5:1, 1:1, and 1:5. YOYO-3 Iodide (Invitrogen, Willow Creek Rd, USA) was added at a final concentration of one in ten thousands (1/10 000). Images were taken every $2 \mathrm{~h}$, and the numbers of apoptotic cells per square millimeter were quantified using the CellPlayer 96-well Kinetic.

\section{Statistical analyses}

Statistical analyses were performed with the unpaired twotailed Student's $t$-test by using Prism software, version 6.0 (GraphPad Software, San Diego, CA, USA). Differences were considered statistically significantat $P<0.05$.

\section{Results}

\section{Expansion of high-affinity TCR (HAT)-redirected CAT}

To redirect CATs by $1 \mathrm{G} 4$ HAT, the cells were transduced twice with lentiviral particles on days 2 and 3 (Fig. 1A-a). The cells were further cultured for expansion for 14-21 d in the presence of IL-2. 1G4 TCR positive cells were detected on day 7 after transduction. CAT transduction with the wild-type $1 \mathrm{G} 4 \mathrm{TCR}\left(\mathrm{K}_{\mathrm{D}}=32 \mu \mathrm{mol} / \mathrm{L}\right)$ and various HATs $\left(\mathrm{K}_{\mathrm{D}} \mathrm{s}=1.07 \mu \mathrm{mol} / \mathrm{L}, 84 \mathrm{nmol} / \mathrm{L}, 5 \mathrm{nmol} / \mathrm{L}\right.$, and $26 \mathrm{pmol} / \mathrm{L}$ ) resulted in TCRV $\beta 13.1$-positive cell populations of $52 \%, 51 \%, 42 \%, 32 \%$, and $51 \%$, respectively. The NY-ESO-1 tetramer staining showed populations of $28 \%, 50 \%, 27 \%, 57 \%$, and $55 \%$, respectively, for these TCR-CATs (Fig. 1B). TCR-CATs expanded by $200 \pm 10$-fold, compared with the $800 \pm 20$-fold expansion of NT-CATs at the end of the 21-day culture period (data not shown).

We also examined whether the transduction of TCRCAT can affect the cell phenotype. We checked the phenotypic markers of CD8, CD3, CD4, and CD56 on NTCAT and TCR-CATs every week. As shown in Supplementary Fig. 1, co-expression frequency of the $\mathrm{CD}^{+} /$ $\mathrm{CD}^{+} \mathrm{T}$ cell population was $78.85 \% \pm 3.13 \%$ for NTCAT and $72.84 \% \pm 5.30 \%$ for TCR-CAT, whereas that of the $\mathrm{CD}^{+} / \mathrm{CD}^{2} 6^{+}$cell population was $14.64 \% \pm 8.67 \%$ for NT-CAT and $17.00 \% \pm 9.47 \%$ for TCR-CAT. The proportions of $\mathrm{CD} 8^{+}$and $\mathrm{CD} 56^{+}$cells were expanded over 21 days. The $\mathrm{CD}^{+} \mathrm{T}$ cell populations were slightly increased from $70 \%$ to $86 \%$ for NT-CAT and from $71 \%$ to $83 \%$ for TCR-CAT. The $\mathrm{CD}^{+} 6^{+}$proportion increased from $5 \%$ to $30 \%$ for NT-CAT and from $5 \%$ to $34 \%$ for TCRCAT. By contrast, the proportion of $\mathrm{CD}^{+} \mathrm{T}$ cells decreased from $55.33 \%$ to $\sim 10.46 \%$ for NT-CAT and from $46.51 \%$ to $18.41 \%$ for TCR-CAT. These results suggested that transduction with lentiviral constructs had no effect on the phenotype of CATs.

\section{Antigen specificity of TCR-CAT}

To determine whether TCR-redirected CATs were antigenspecific, we investigated their activity against peptidepulsed T2 cells by using ELISPOT and LDH assays. T2 cells were pulsed with the NY-ESO-1 $1_{157-165}$ (SLLMWITQV) peptide or an irrelevant SAGE-1 peptide VFSTVPPAFI and used as stimulators for TCR-CAT and NTCATs. TCR-CATs with $\mathrm{K}_{\mathrm{D}} \mathrm{S}$ of $32 \mu \mathrm{mol} / \mathrm{L}, 1.07 \mu \mathrm{mol} / \mathrm{L}$, and $84 \mathrm{nmol} / \mathrm{L}$ specifically expressed large amounts of IFN- $\gamma$ in response to $\mathrm{T} 2$ cells presenting cognate peptide while remaining inert to those presenting the VFSTVPPAFI control peptide (Fig. 2A). However, the other two TCR-CATs, namely, $5 \mathrm{nmol} / \mathrm{L}$ and $26 \mathrm{pmol} / \mathrm{L}$, showed nonspecific activation in response to control peptidepulsed T2 cells, suggesting that they might respond to HLA A2 presenting self-peptides in accordance with previous findings [29].

Similar outcomes were observed in the cytotoxicity assays, whereas $32 \mu \mathrm{mol} / \mathrm{L}, 1.07 \mu \mathrm{mol} / \mathrm{L}$, and $84 \mathrm{nmol} / \mathrm{L}$ TCR-CATs demonstrated a higher level of specific pulsed T2 killing than NT-CATs (Fig. 2B). By contrast, TCR affinity with a low nanomolar $\mathrm{K}_{\mathrm{D}}$, such as $5 \mathrm{nmol} / \mathrm{L}$ or $26 \mathrm{pmol} / \mathrm{L}$, conferred the CATs with nonspecific killing ability against both the NY-ESO-1 and irrelevant SAGE-1 peptide-pulsed T2 cells. 

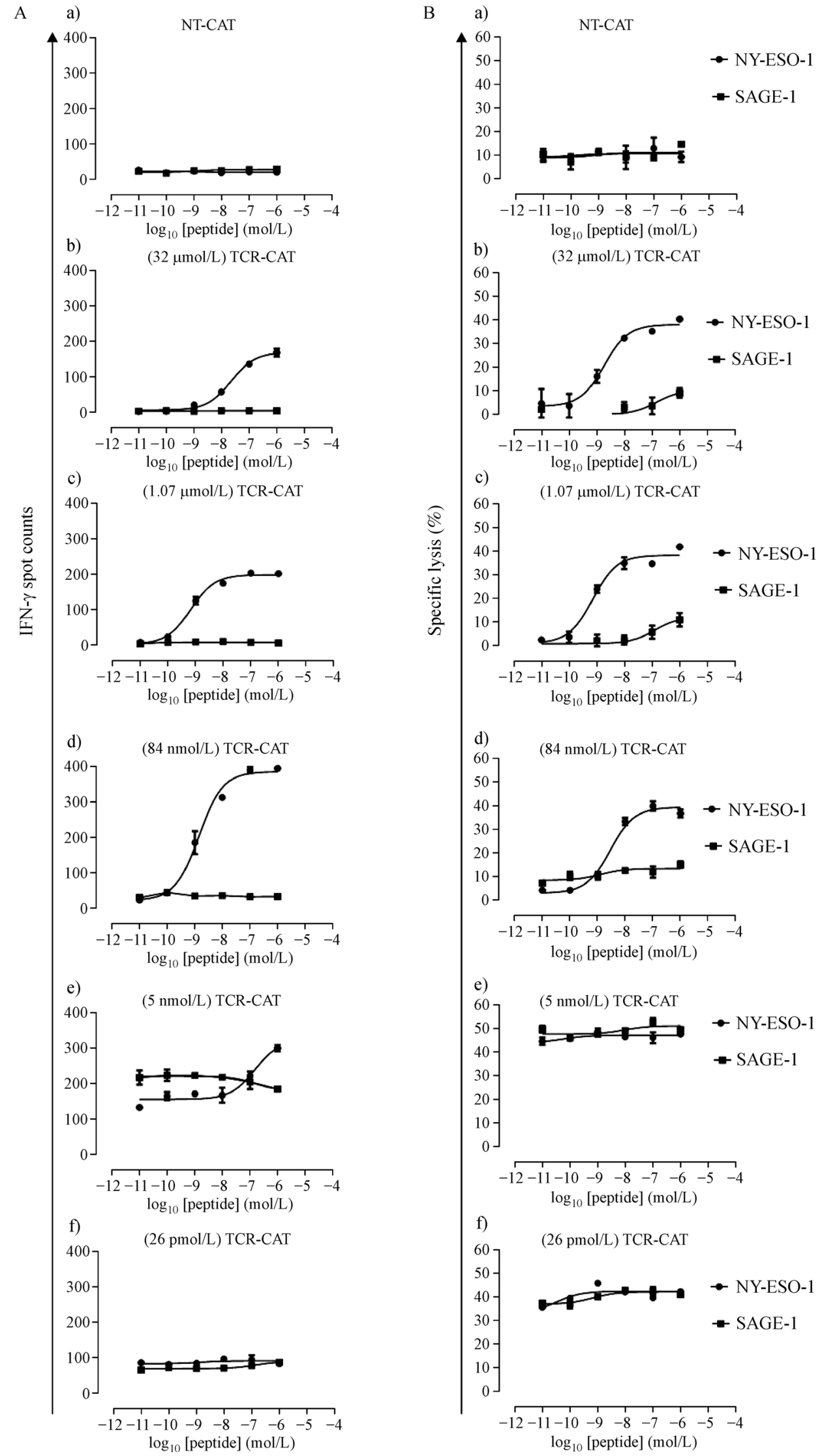

Fig. 2 Antigen-specific recognition by high-affinity TCRs expressed on CAT cells. (A) Cytokine release assay. A total of $2 \times 10^{3}$ transduced TCRCAT $(32 \mu \mathrm{mol} / \mathrm{L}, 1.07 \mu \mathrm{mol} / \mathrm{L}, 84 \mathrm{nmol} / \mathrm{L}, 5 \mathrm{nmol} / \mathrm{L}$, and $26 \mathrm{pmol} / \mathrm{L})$ or nontransduced CAT (NT-CAT) cells were cocultured with peptide-pulsed T2 cells at an E:T ratio of 1:10 for $20 \mathrm{~h}$. The amount of peptide loaded on T2 cells was in serial concentrations of antigen NY-ESO-1 $157-165$ (SLLMWITQV) peptide or an irrelevant peptide SAGE-1 VFSTVPPAFI. (B) Cytotoxicity assays. The effector cells were cocultured with peptidepulsed T2 cells at serial concentration of the NY-ESO-1 peptide or the irrelevant peptide SAGE-1 for $20 \mathrm{~h}$. The E:T ratio is 5:1 with the constant number of target cells $\left(2 \times 10^{4}\right)$. Data shown are mean \pm standard deviation (SD) of three representative tests. 


\section{Roles of various HATs in redirecting CAT against cancer cell lines}

We analyzed the functions of transduced TCR-CAT and NT-CAT cells against NY-ESO- $1^{+}$tumor cells by using ELISPOT assays. The TCR-CATs secreted more IFN- $\gamma$ and granzyme B than the NT-CATs by using A375 or Mel624 (HLA-A2 ${ }^{+} / \mathrm{NY}^{-E S O}-1^{+}$) as the target cells (Fig. 3A and 3B). Three TCR-CATs, namely, $32 \mu \mathrm{mol} / \mathrm{L}$, $1.07 \mu \mathrm{mol} / \mathrm{L}$, and $84 \mathrm{nmol} / \mathrm{L}$, showed good activities against A375 and Mel624 tumor cells but not against Mel526 (HLA-A2 ${ }^{+} / \mathrm{NY}^{-E S O}-1^{-}$) and NCI-H1650 $\left(\mathrm{HLA}-\mathrm{A} 2^{+} / \mathrm{NY}-\mathrm{ESO}-1^{-}\right.$) cells. However, the other two TCR-CATs, namely, $5 \mathrm{nmol} / \mathrm{L}$ and $26 \mathrm{pmol} / \mathrm{L}$, showed activities against all target cells. Using antigen-overexpressed K562 cells (human erythroleukemic cells transfected with HLA*A02:01 and NY-ESO-1), TCRCATs showed significantly better activity against these cells compared with NT-CATs although K562 can be naturally killed by CATs, i.e., NT-CATs (Fig. 3C and 3D).

LDH assays were used to measure cytotoxicity. Similar to the cell-activation assay results, TCR-CATs demonstrated significantly better killing ability than NT-CAT against A375 and Mel624 at all E:T ratios (Fig. 3E). Importantly, the cytotoxicity of TCR-CATs $32 \mu \mathrm{mol} / \mathrm{L}$, $1.07 \mu \mathrm{mol} / \mathrm{L}$, and $84 \mathrm{nmol} / \mathrm{L}$ were specific for A375 and Mel624 tumor cells. By contrast, the other two TCR-CATs, $5 \mathrm{nmol} / \mathrm{L}$ and $26 \mathrm{pmol} / \mathrm{L}$, showed significant killing ability against all tested cells including the negative controls of NCI-H1650 and Mel526. These results indicated that the TCR-CATs expressing super high affinity TCRs might exhibit significant cross-reactivity with self-peptides presented by HLA-A2.

\section{Degranulation of TCR-CATs}

Although the granzyme B releasing assay might provide a good indication of the degranulation ability of TCR-CATs, we investigated the mechanism further by measuring the expression of the degranulation marker CD107a that is known to be a surrogate marker of CD8 T cell killing [30]. A significant difference was observed in the proportion of CD107a expression between TCR-CAT and NT-CAT (Fig. 4). The $1.07 \mu \mathrm{mol} / \mathrm{L}$ TCR-CAT showed better CD107a expression than the wild-type $32 \mu \mathrm{mol} / \mathrm{L}$ TCRCAT and the high-affinity $84 \mathrm{nmol} / \mathrm{L}$ TCR-CAT. This result was in good agreement with the IFN- $\gamma$ and granzyme B secretion results and cell killing ability reported above. These findings suggest that CD107a as a marker of TCRCAT activation plays a central role in the cell-mediated lysis of target cells.

\section{Enhancement of the antitumor activities of TCR-CAT is TCR-dependent}

To examine whether the enhanced antitumor activities of TCR-CAT were related to the transduced TCR, we used the soluble HAT to compete the binding of the target cell antigen by the membrane-anchored TCR on the CAT. Tumor cells U266-B1 and A375 (HLA-A2 ${ }^{+}$NY-ESO- ${ }^{+}$) and Mel526 (HLA-A2 ${ }^{+} / \mathrm{NY}$-ESO- $1^{-}$) were used as targets for the assays. Higher level IFN- $\gamma$ productions of TCR-CAT were observed by incubating the T cells with U266-B1 and A375 target cells without soluble HAT pre-incubation, compared with NT-CAT. After the pHLA of the target cells was blocked by the soluble HAT, TCR-CAT showed a significant reduction in IFN- $\gamma$ spots in response to U266-B1 and A375 (Fig. 5A). A TCR-CAT cytotoxicity LDH assay also revealed similar patterns to the ELISPOT results. The specific lysis was significantly reduced when the antigens of U266-B1 and A375 target cells were blocked with the soluble HAT (Fig. 5B). However, HAT blocking had no effect on the function of NT-CAT. To further investigate whether the increased cytotoxicity and cytokine release of TCR-CAT was HLA-dependent, we treated the tumor cells with W6/32 mAb (HLA class I mAb) or an isotype control (IgG2a). The production of IFN- $\gamma /$ granzyme B by the TCRCAT was reduced by the antibody blocking class-I on the cells similar to the NY-ESO- $1^{+} / \mathrm{HLA}-\mathrm{A} 2^{+}$tumor cell lysis, compared with unblocked antigen binding of target cells (Supplementary Fig. 2).

\section{Kinetics of TCR-CAT-mediated cancer cell death}

The kinetics of TCR-CAT-mediated cancer cell death was investigated using an IncuCyte apoptosis assay. A375 $\left(\mathrm{HLA}-\mathrm{A} 2^{+} / \mathrm{NY}-\mathrm{ESO}-1^{+}\right.$) and NCI-H1650 (HLA-A2 ${ }^{+} / \mathrm{NY}-$ ESO- $1^{-}$) tumor cell lines were cocultured with TCR-CAT or NT-CAT effector cells at $37^{\circ} \mathrm{C}$. First, we investigated the killing kinetic of the tumor cell lines by TCR-CAT at $\mathrm{E}: \mathrm{T}$ ratios of $5: 1,1: 1$, and 1:5. Our results indicated that different E:T ratios had significant effects on the killing kinetics for antigen-positive target cells (A375) (Supplementary Fig. 3). Further investigation was carried out on HATs of $32 \mu \mathrm{mol} / \mathrm{L}, 1.07 \mu \mathrm{mol} / \mathrm{L}$, and $84 \mathrm{nmol} / \mathrm{L}-$ transduced CAT and NT-CAT with an E:T ratio of 5:1. TCR-CAT started killing A375 cells at approximately 12 $16 \mathrm{~h}$ after the co-incubation period. By contrast, weak killing of A375 cells by NT-CAT was observed only at approximately $48 \mathrm{~h}$ (Fig. 6A). No significant killing was observed in NCI-H1650 (Fig. 6B). These results were consistent with those of the cytokine release and $\mathrm{LDH}$ assays, in which $84 \mathrm{nmol} / \mathrm{L}$ TCR-CAT showed less efficient killing of A375. 


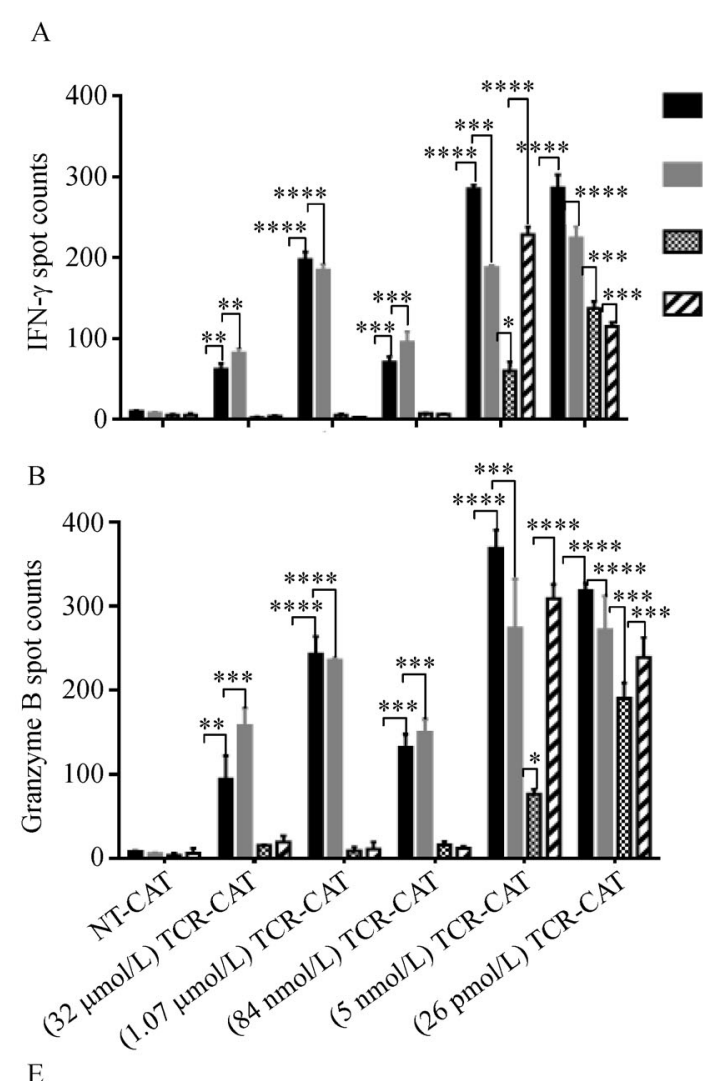

E a)
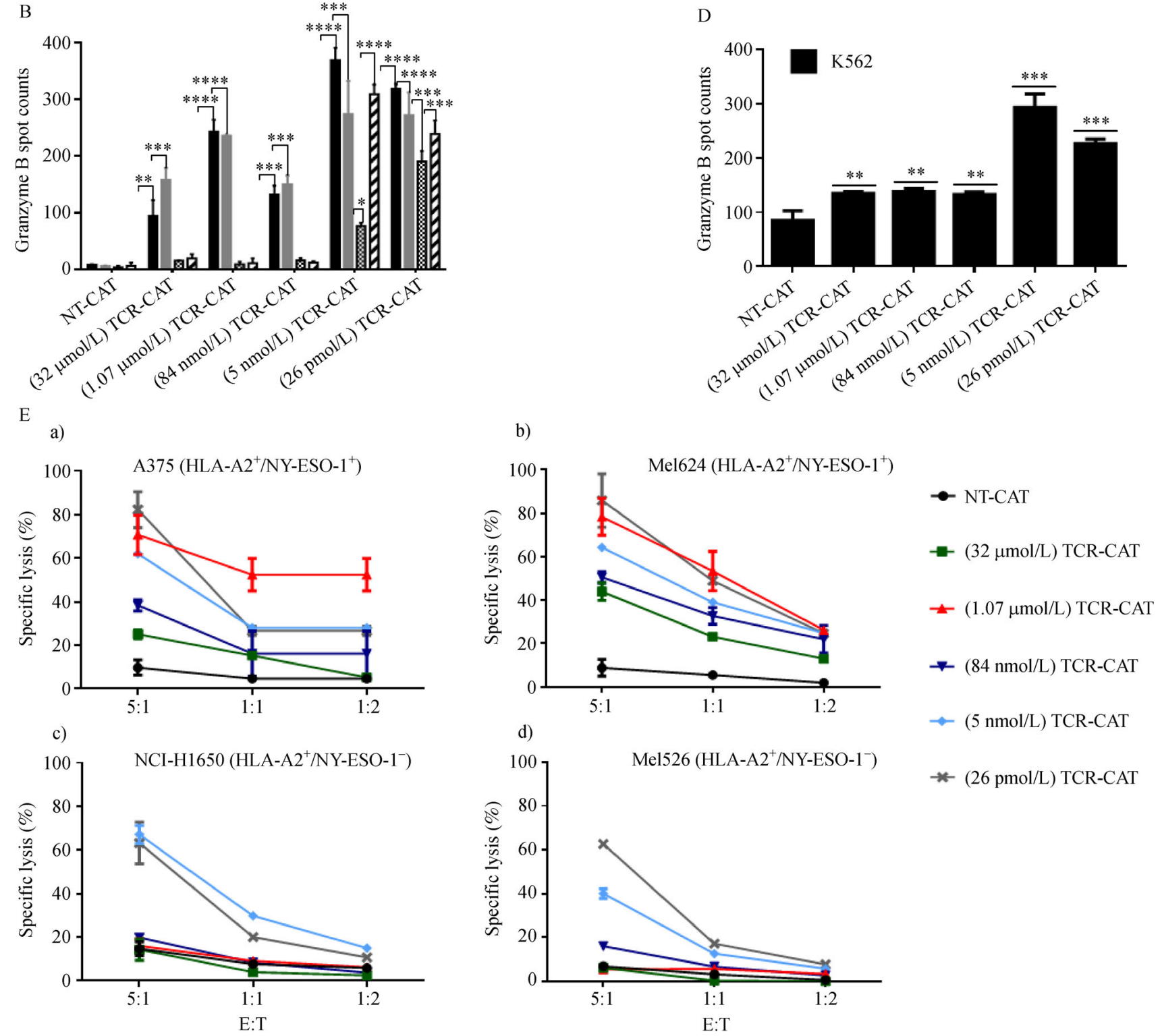

Fig. 3 Functions of high-affinity TCRs (1G4 HATs) redirected CAT cell against testis antigens on cancer cells. The enhanced T cell activation was detected after 1G4 HATs transfected CAT cells with the tumor cells at an E:T ratio of 1:10 by ELISPOT assays. (A and C) IFN- $\gamma$ release; (B and D) Granzyme B release. Nontransduced CAT (NT-CAT) cells and transduced-1G4 TCRs $(32 \mu \mathrm{mol} / \mathrm{L}, 1.07 \mu \mathrm{mol} / \mathrm{L}, 84 \mathrm{nmol} / \mathrm{L}, 5 \mathrm{nmol} / \mathrm{L}$, and $26 \mathrm{pmol} / \mathrm{L}$ ) CAT cells were stimulated with target cells A375 (HLA-A2 ${ }^{+} / \mathrm{NY}-\mathrm{ESO}-1^{+}$), Mel624 (HLA-A2 $\left.{ }^{+} / \mathrm{NY}-\mathrm{ESO}-1^{+}\right)$, Mel526 $\left(\mathrm{HLA}-\mathrm{A} 2^{+} / \mathrm{NY}^{-}\right.$ ESO-1 7 ), NCI-H1650 (HLA-A2 ${ }^{+}$NY-ESO-1 7 ), and K562 (HLA-A2 ${ }^{+} /$NY-ESO-1 $^{+}$). (E) Enhanced cytotoxicity of TCR-CAT for target cells. The cytotoxic activities were detected by LDH assay at various E:T ratios of 5:1, 1:1 or 1:2. The target cells A375, Mel624, NCI-H1650, and Mel526 were pre-incubated with effector cells (NT-CAT or TCR-CAT) for $20 \mathrm{~h}$ with the constant number of target cells $\left(2 \times 10^{4}\right)$. Data shown are mean \pm SD of three representative tests. Asterisks $(*)$ indicate statistical significance $(* P<0.05 ; * * P<0.01 ; * * * P<0.001 ; * * * * P<0.0001)$ of TCR-CAT compared with NT-CAT. 
A $\quad$ A375 $\left(\mathrm{HLA}^{-\mathrm{A} 2^{+}}{ }^{\mathrm{N}} \mathrm{NY}-\mathrm{ESO}-1^{+}\right)$

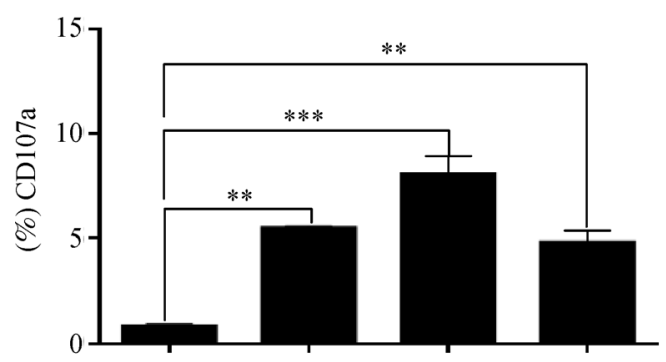

$\mathrm{C}$

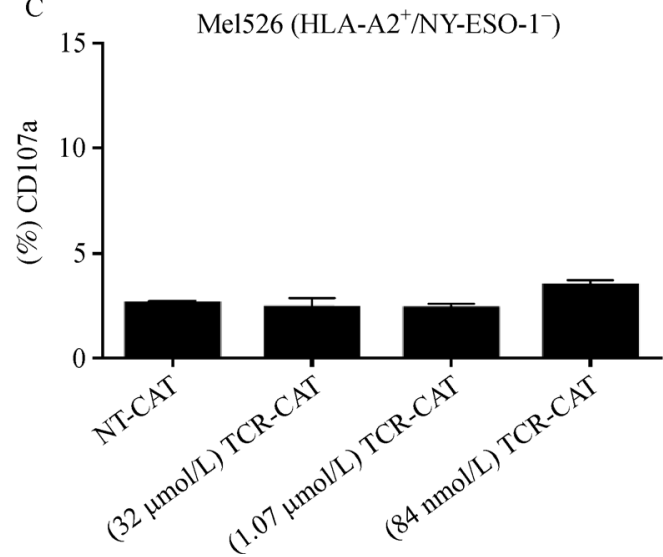

B

Me1624 (HLA-A2 ${ }^{+}$NY-ESO- ${ }^{+}$)
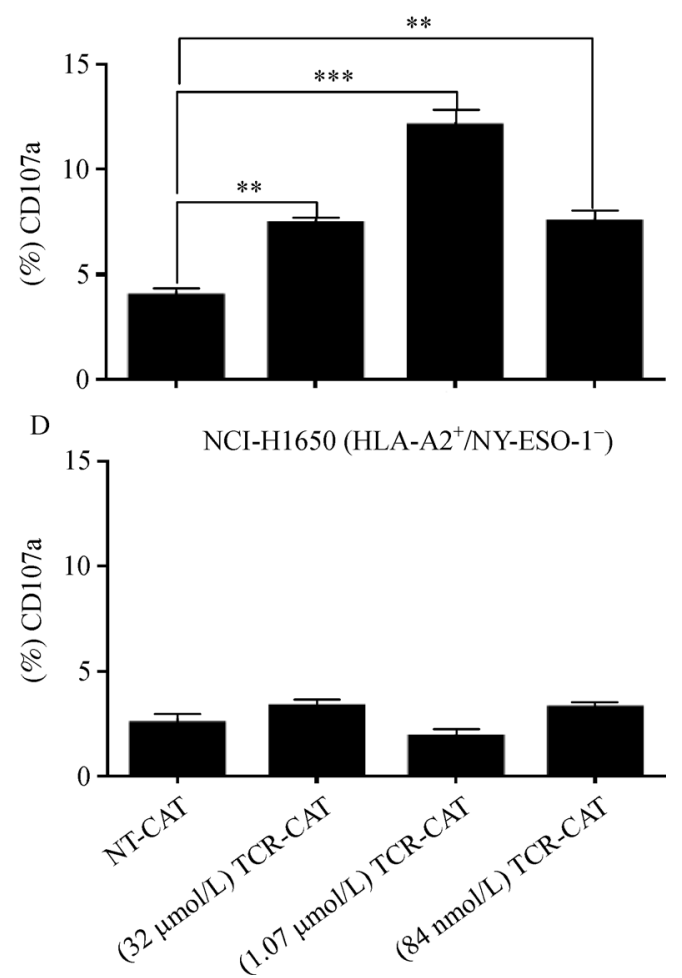

Fig. 4 CD107a expression of activated TCR-CAT cells. Nontransduced-CAT (NT-CAT) and TCR-CAT (32 $\mu \mathrm{mol} / \mathrm{L}, 1.07 \mu \mathrm{mol} / \mathrm{L}$, and $84 \mathrm{nmol} / \mathrm{L})$ cells were stimulated with HLA-A2 ${ }^{+} / \mathrm{NY}-\mathrm{ESO}-1^{+}$target cells of A375 or Mel624 and HLA-A2 ${ }^{+} / \mathrm{NY}-\mathrm{ESO}-1^{-}$cells of Mel526 or NCI-H1650 at E:T ratio of $1: 1$ for $16 \mathrm{~h}$ with the constant number of target cells $\left(2 \times 10^{4}\right)$. Percentages of CD107a positive cell population were gated electronically in the channel CD107a (PE) with CD3 (APC). Data shown are mean \pm SD of three representative tests. Asterisks $\left({ }^{*}\right)$ indicate statistical significance ( $\left.P<0.05 ;{ }^{* *} P<0.01 ; * * *<0.001\right)$ of TCR-CAT compared with NT-CAT.

\section{TCR-CAT demonstrated better killing function than the equivalent TCR-T}

We compared the functional activity of TCR-CAT with TCR transduced peripheral blood mononuclear cells (TCR-T) by using ELISPOT and LDH assays. The TCR $1.07 \mu \mathrm{mol} / \mathrm{L}$ was used to transduce CAT and $\mathrm{T}$ cells (preparation of CAT and T cells described in the Materials and methods section), and the transduction efficiencies of TCR-CAT and TCR-T were $31 \%(n=3)$ and $44 \%(n=3)$, respectively.

TCR-CAT exerted markedly enhanced in vitro antitumor activity compared with TCR-T cells. In the cytokine release assay, IFN- $\gamma$ production was significantly increased by TCR-CAT-targeting A375 $(P<0.001)$ and Mel624 $(P<0.01)$, compared with TCR-T (Fig. 7A). Similarly, a significant increase was observed in granzyme B release from TCR-CAT compared with TCR-T against A375 and Mel624 $(P<0.05)$ (Fig. 7B). Similar to the cytokine release assay, TCR-CAT demonstrated significantly enhancement of in vitro cytotoxicity for A375 and Mel624 $(P<0.01)$ compared with TCR-T (Fig. 7C). No significant difference was observed for TCR-CAT or TCR-
T against negative target cells (Mel526 and NCI-H1650) in either the cytokine release or the cytotoxicity assays. These results were supported by the images taken in real time by InCucyte assay (Supplementary Fig. 4). TCR-CAT demonstrated rapid and early killing of the target cells (A375) compared with TCR-T cells. After $16 \mathrm{~h}$ of incubation, many apoptotic cells were seen in TCR-CAT, whereas TCR-T remained unchanged. The images taken at $36 \mathrm{~h}$ showed that $100 \%$ of the target cells had been killed by TCR-CAT, whereas many viable target cells were still observed in the TCR-T cell assay. No killing of targets cells was observed in NT-CAT or nontransduced-T cells. In the case of targeting negative control cell NCI-H1650, no significant difference was observed in any of the groups (data not shown). These results suggest that TCR-CAT had stronger $\mathrm{T}$ cell-mediated tumor cell killing ability compared with TCR-T cells.

\section{Discussion}

In this study, we investigated the antitumor activity of CATs modified by TCR with various affinities for targeting 
A
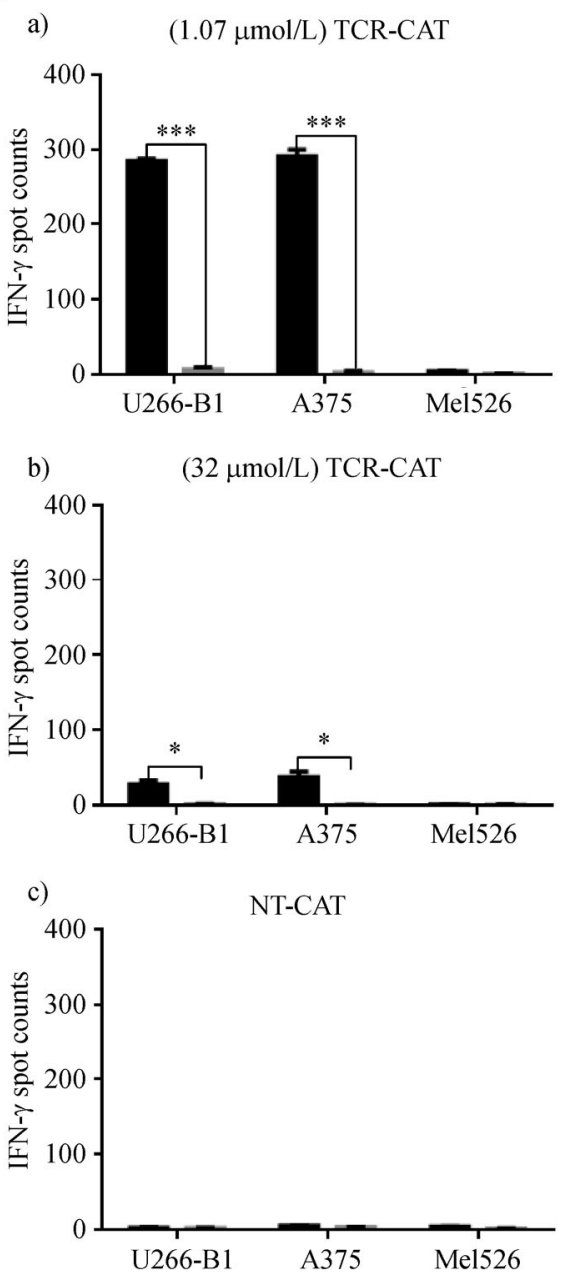

B
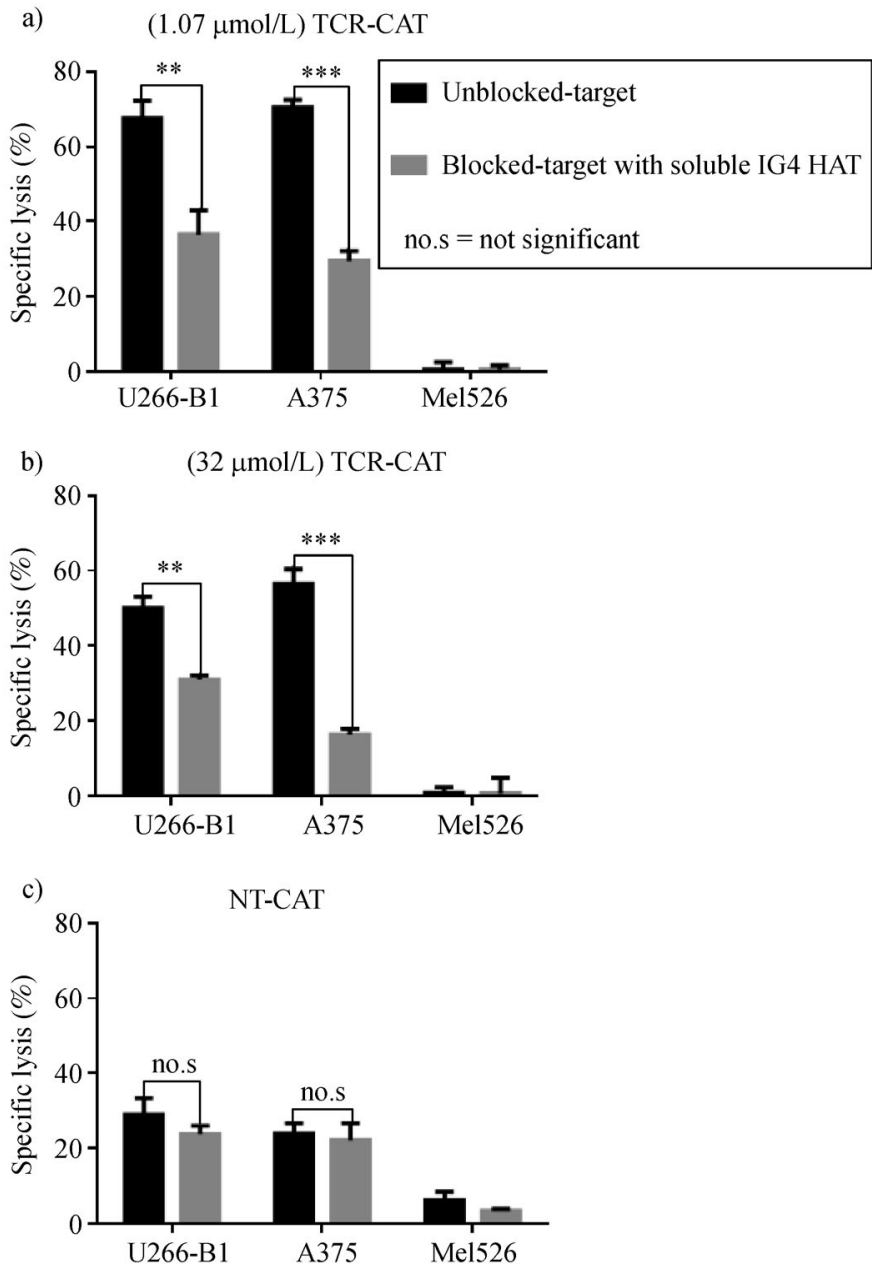

Fig. 5 Enhanced TCR-CAT killing tumor target cells was attenuated by soluble 1 G4 HAT. The HLA-A2 ${ }^{+} / \mathrm{NY}-\mathrm{ESO}-1^{+}$target cells of U266-B1 or

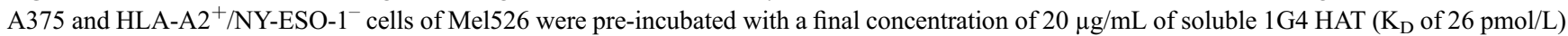
for $30 \mathrm{~min}$, followed by coculture with $2 \times 10^{3}$ of CAT cells or TCR-CAT $(1.07 \mu \mathrm{mol} / \mathrm{L})$ and TCR-CAT $(32 \mu \mathrm{mol} / \mathrm{L}) \mathrm{cells}$ at E:T = 1:10 for $20 \mathrm{~h}$ (ELISPOT assay (A)), or with $1 \times 10^{5}$ of the cells at E:T $=5: 1$ for $20 \mathrm{~h}$ (LDH assay (B)). Data shown are mean $\pm \mathrm{SD}$ of three representative tests. Asterisks $(*)$ indicate statistical significance $\left({ }^{*} P<0.05\right.$; $\left.{ }^{*} P<0.01 ; * * P<0.001\right)$ of soluble $1 \mathrm{G} 4$ HAT unblocked (black bar) compared with blocked antigen binding on the cells (gray bar).

HLA-A*02:01-restricted cancer/testis antigen NY-ESO$1_{157-165}$. CATs consist of a heterogeneous population of polyclonal $\mathrm{CD}^{+} / \mathrm{CD}^{-} 6^{-} \mathrm{T}$ lymphocytes and $\mathrm{CD}^{+} /$ $\mathrm{CD}^{2} 6^{+}$NKT phenotype with high proliferation but with low cytotoxicity, which is able to mediate HLA-unrestricted cytotoxic activity against a broad range of tumors $[14,28,31]$. The easiness and safety of expanding CATs over a short period [32] are important factors to consider in clinical trials of cancer immunotherapy, as clearly demonstrated by our data showing that CATs expanded approximately 800 -fold within 3 weeks of culture. Few clinical trials with genetically modified CATs have been reported. The establishment of standard protocols may be beneficial to prevent tumor relapse with a reduced risk of graft-versus-host-disease for immunotherapy. Furthermore, the exact mechanisms by which CATs induce tumor recognition and targeted cytotoxicity are not fully understood. A previous study by using variants of the $1 \mathrm{G} 4$ TCR specific for NY-ESO-1 to modify T cells showed that $\mathrm{CD} 8^{+} \mathrm{T}$ cells transduced with intermediate- and highaffinity TCR variants demonstrated specific antigen recognition, whereas increasing affinity resulted in nonspecific recognition [30]. Modified-CD4 ${ }^{+} \mathrm{T}$ cells with those variant TCR affinities also increased the reactivity to the target cells [8]. However, optimal TCR affinities in $\mathrm{CD}^{+} \mathrm{T}$ cells are known to be higher than in $\mathrm{CD}^{+} \mathrm{T}$ cells [4].

The present work demonstrated that CATs engineered 


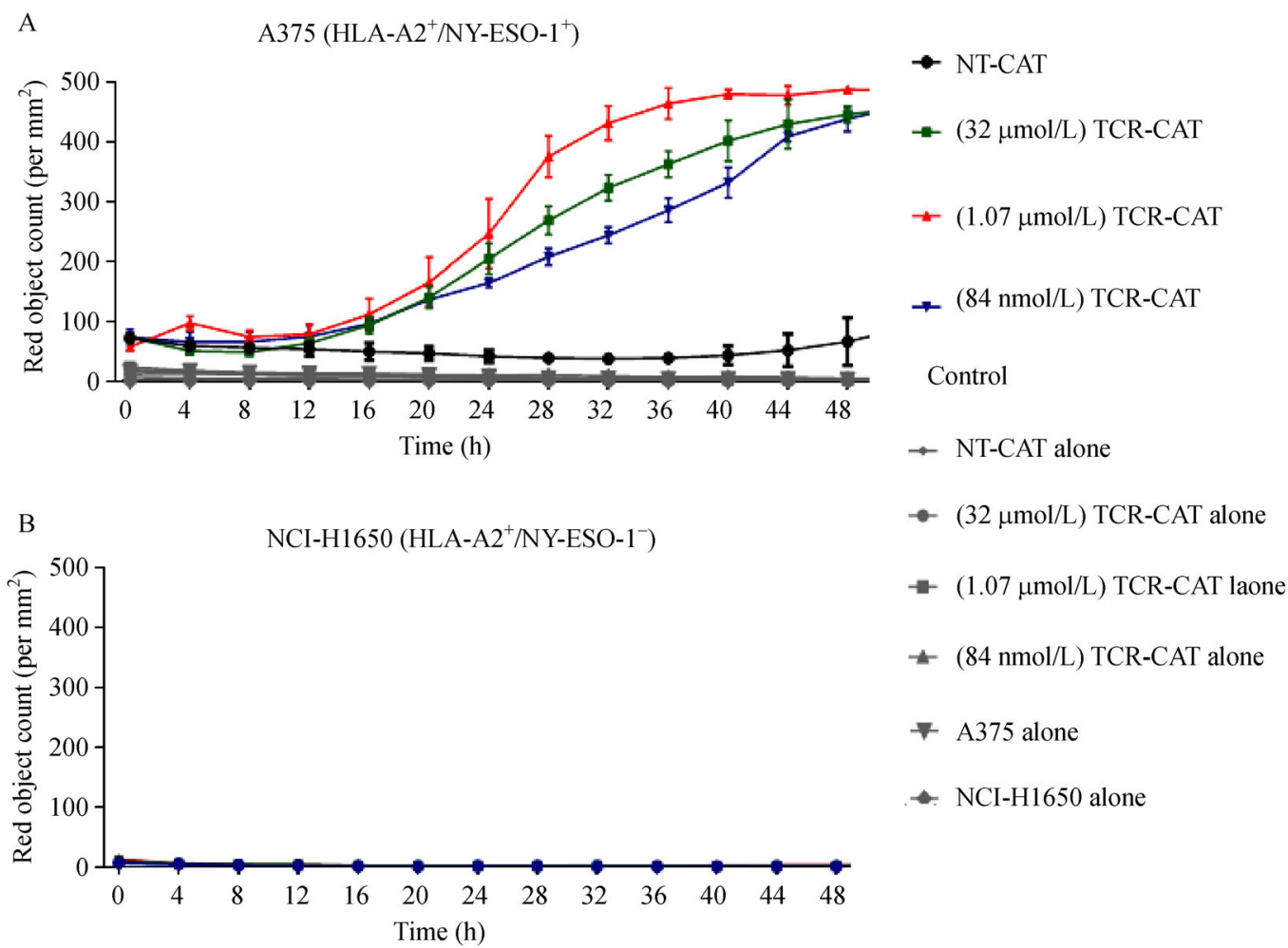

Fig. 6 TCR-CAT cells targeted cancer cell killing measured in real time. A total of $7 \times 10^{3}$ of targeted cells A375 (HLA-A2 $2^{+} / \mathrm{NY}-\mathrm{ESO}-1^{+}$) or NCIH1650 (HLA-A2 ${ }^{+}$/NY-ESO-1 7 ) were incubated overnight, followed by cocultured with nontransduced CAT (NT-CAT) or TCR-CAT cells $(32 \mu \mathrm{mol} / \mathrm{L}, 1.07 \mu \mathrm{mol} / \mathrm{L}$, and $84 \mathrm{nmol} / \mathrm{L}$ ) at E:T ratio of 5:1 for $48 \mathrm{~h}$. Images were taken at intervals of $2 \mathrm{~h}$. (A) A375 (antigen positive cells). (B) NCIH1650 (antigen negative cells). Data shown are mean \pm SD of three representative tests.

with low micromolar $\mathrm{K}_{\mathrm{D}}$ TCR show specific recognition of the cancer antigen NY-ESO-1 with good cancer-killing efficacy. Our data showed that CAT engineered with $32 \mu \mathrm{mol} / \mathrm{L}, 1.07 \mu \mathrm{mol} / \mathrm{L}$, and $84 \mathrm{nmol} / \mathrm{L}$ TCRs specifically recognized $\mathrm{HLA}-\mathrm{A} 2^{+} / \mathrm{NY}$-ESO- ${ }^{+}$Ag tumor target cells in cytotoxicity, cytokine release, and real-time apoptosis assays. As shown in Fig. 3E, the lysis of TCR-CATs $32 \mu \mathrm{mol} / \mathrm{L}, 1.07 \mu \mathrm{mol} / \mathrm{L}$, and $84 \mathrm{nmol} / \mathrm{L}$ was specific for tumor target cells $\left(\mathrm{HLA}-\mathrm{A} 2^{+} / \mathrm{NY}-\mathrm{ESO}-1^{+}\right.$). Notably, the cytotoxic activity of $1.07 \mu \mathrm{mol} / \mathrm{L}$ TCR showed significantly better killing ability than $32 \mu \mathrm{mol} / \mathrm{L}$ and $84 \mathrm{nmol} / \mathrm{L}$ of TCRs at all E:T ratios. However, $84 \mathrm{nmol} / \mathrm{L}$ TCRtransduced CAT showed only a weak ability to kill tumor targets. In contrast to cells transduced with moderate affinity-enhanced TCRs, those with an excessive increase in TCR affinity killed both positive target cells (HLA-A2 ${ }^{+}$/ NY-ESO- $1^{+}$) and negative target cells (HLA-A2 ${ }^{+} / \mathrm{NY}-$ ESO- $1^{-}$) in accordance with previous findings [33]. Highaffinity TCRs may allow CATs to respond to target cells bearing a low level of cognate peptide.

A previous report also compared the activities of CATs and $\mathrm{T}$ cells stimulated with anti-CD3/CD28 microbeads stimulated against myelomonocytic leukemia [34] and demonstrated that CATs had superior cytotoxicity. We compared the activities of TCR-CAT and TCR-T against melanoma tumor cells. Interestingly, the cytotoxicity and cytokine release experiments proved that high-affinity TCR-modified CAT exhibited significantly superior cytotoxicity against melanoma cell lines. The difference in cytotoxicity or cytokine release between TCR-CAT and TCR-T cells was significant after $14 \mathrm{~d}$ of culture. The highly mixed population of $T$ cells could be an important reason behind the superior cytotoxicity of TCR-CATs over TCR-T cells. TCR-CATs also started to kill target cells earlier (observed at $16 \mathrm{~h}$ ) than the TCR-T cells and achieved a $100 \%$ kill rate over a $48 \mathrm{~h}$ monitoring experiment. A few fundamental differences between TCR-CAT and TCR-T cells could be explained by the higher proportion of $\mathrm{CD}^{+}$cells in TCR-CATs than in TCR-T cells [35]. The non-HLA-restricted CAT-mediated cytotoxicity of allogeneic targets may also contribute to the enhancement of cancer cell killing efficacy [35]. CATs modified with a micromolar affinity TCR may show promise in clinical trials for cancer immunotherapy. 
A

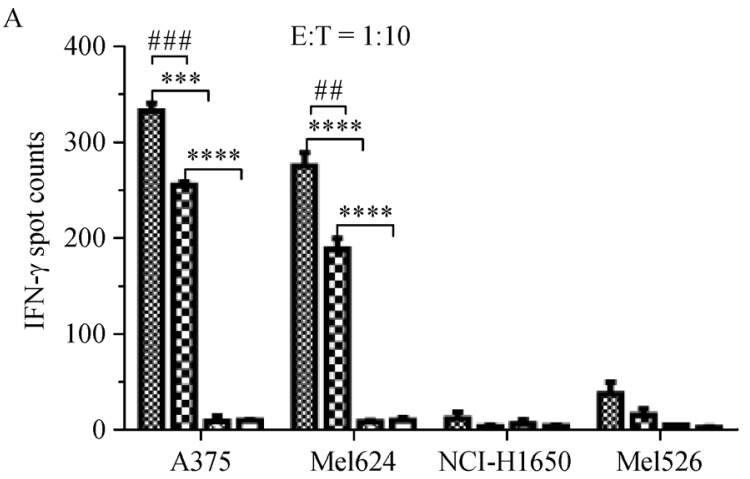

$\mathrm{C}$

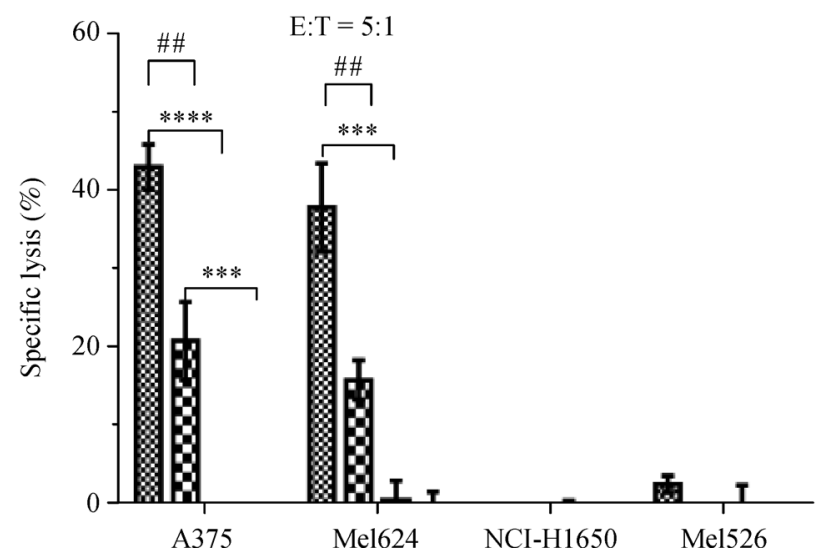

B

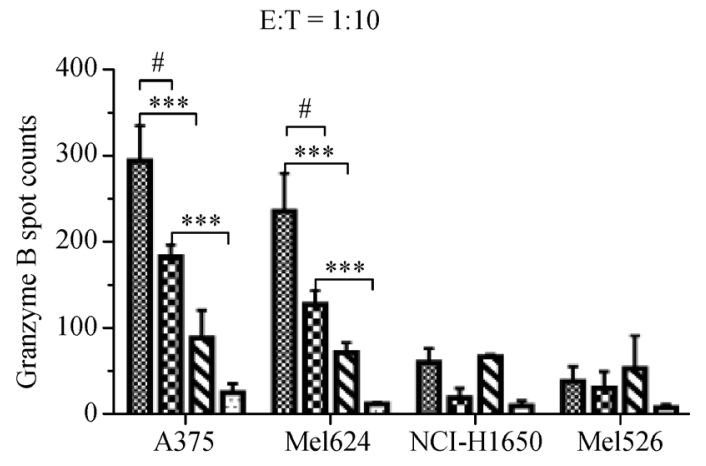

Fig. 7 Comparison of the activities of TCR-CAT and TCR-T cells transduced with TCR-1.07 $\mu \mathrm{mol} / \mathrm{L}$. The efficiency of TCR-CAT and TCR-T cell transduction with the TCR-1.07 $\mu \mathrm{mol} / \mathrm{L}$ showed $31 \%$ and $44 \%$, respectively, with staining by anti-mouse TCR $\beta-\mathrm{C}$ domain $\mathrm{mAb}$. The activities of TCR-CAT and TCR-T cells were measured for secretions of IFN- $\gamma(\mathrm{A})$ and granzyme B (B) at day 14 of culturing. A total of $2 \times 10^{3}$ of TCR-CAT, TCR-T, CAT, or T cells were cocultured with HLA-A2 ${ }^{+} / \mathrm{NY}-\mathrm{ESO}-1^{+}$cells of A375 or Mel624 and HLA-A2 ${ }^{+} / \mathrm{NY}-\mathrm{ESO}-1^{-}$cells of NCI-H1650 or Mel526 at E:T $=1: 10$ for $20 \mathrm{~h}$. (C) Cytotoxic activity of TCR-CAT compared with TCR-T cells. The target cells A375, Mel624, NCI-H1650 or Mel526 were pre-incubated with effector cells at $\mathrm{E}: \mathrm{T}=5: 1$ for $20 \mathrm{~h}$ with a constant number of target cells $\left(2 \times 10^{4}\right)$. Data shown are mean $\pm \mathrm{SD}$ of three representative tests. Asterisks $(*)$ indicate statistical significance $\left(* P<0.05 ;{ }^{* *} P<0.01 ; * * * P<0.001 ; * * * * P<0.0001\right)$ of TCR-CAT or TCR-T cells compared with control nontransduced CAT or T cells (NT-CAT or NT-T). Hashes $\left({ }^{\#} P<0.05,{ }^{\# \#} P<0.01,{ }^{\# \# \#} P<0.001\right)$ indicate statistical significant differences between TCR-CAT and TCR-T cells.

\section{Acknowledgements}

This study was supported by the Sciences and Technology Program of Guangzhou (No. 201504010016); the National Key R\&D program (No. 2016YFC1303404); and the Sciences and Technology Program of Guangzhou (No. 201704020220). The study was also sponsored by the CAS-TWAS President's PhD Fellowship Program awarded to Synat Kang.

\section{Compliance with ethics guidelines}

Synat Kang, Yanyan Li, Yifeng Bao, and Yi Li declare that they have no conflicts of interest. All procedures followed were in accordance with the ethical standards of the responsible committee on human experimentation (institutional and national) and with the Helsinki Declaration of 1975, as revised in 2000 (5). Informed consent was obtained from all healthy donors for inclusion in the study.
Electronic Supplementary Material Supplementary material is available in the online version of this article at https://doi.org/ $10.1007 / \mathrm{s} 11684-018-0677-1$ and is accessible for authorized users.

Open Access This article is distributed under the terms of the Creative Commons Attribution 4.0 International License (http:// creativecommons.org/licenses/by/4.0/), which permits unrestricted use, distribution, and reproduction in any medium, provided the appropriate credit is given to the original author(s) and the source, and a link is provided to the Creative Commons license, indicating if changes were made.

\section{References}

1. Morgan RA, Dudley ME, Wunderlich JR, Hughes MS, Yang JC, Sherry RM, Royal RE, Topalian SL, Kammula US, Restifo NP, Zheng Z, Nahvi A, de Vries CR, Rogers-Freezer LJ, Mavroukakis 
SA, Rosenberg SA. Cancer regression in patients after transfer of genetically engineered lymphocytes. Science 2006; 314(5796): 126-129

2. Morgan RA, Chinnasamy N, Abate-Daga D, Gros A, Robbins PF, Zheng Z, Dudley ME, Feldman SA, Yang JC, Sherry RM, Phan GQ, Hughes MS, Kammula US, Miller AD, Hessman CJ, Stewart AA, Restifo NP, Quezado MM, Alimchandani M, Rosenberg AZ, Nath A, Wang T, Bielekova B, Wuest SC, Akula N, McMahon FJ, Wilde S, Mosetter B, Schendel DJ, Laurencot CM, Rosenberg SA. Cancer regression and neurological toxicity following anti-MAGE-A3 TCR gene therapy. J Immunother 2013; 36(2): 133-151

3. Robbins PF, Morgan RA, Feldman SA, Yang JC, Sherry RM, Dudley ME, Wunderlich JR, Nahvi AV, Helman LJ, Mackall CL, Kammula US, Hughes MS, Restifo NP, Raffeld M, Lee CC, Levy CL, Li YF, El-Gamil M, Schwarz SL, Laurencot C, Rosenberg SA. Tumor regression in patients with metastatic synovial cell sarcoma and melanoma using genetically engineered lymphocytes reactive with NY-ESO-1. J Clin Oncol 2011; 29(7): 917-924

4. Tan MP, Dolton GM, Gerry AB, Brewer JE, Bennett AD, Pumphrey NJ, Jakobsen BK, Sewell AK. Human leucocyte antigen class Iredirected anti-tumour $\mathrm{CD}^{+} \mathrm{T}$ cells require a higher $\mathrm{T}$ cell receptor binding affinity for optimal activity than $\mathrm{CD}^{+} \mathrm{T}$ cells. Clin Exp Immunol 2017; 187(1): 124-137

5. Lanier LL, Yu G, Phillips JH. Analysis of FcyRIII (CD16) membrane expression and association with $\mathrm{CD} 3 \zeta$ and $\mathrm{Fc}$ epsilon RI- $\gamma$ by site-directed mutation. J Immunol 1991; 146(5): 1571-1576

6. Xing Y, Hogquist KA. T-cell tolerance: central and peripheral. Cold Spring Harb Perspect Biol 2012; 4(6): a006957

7. Liddy N, Bossi G, Adams KJ, Lissina A, Mahon TM, Hassan NJ, Gavarret J, Bianchi FC, Pumphrey NJ, Ladell K, Gostick E, Sewell AK, Lissin NM, Harwood NE, Molloy PE, Li Y, Cameron BJ, Sami M, Baston EE, Todorov PT, Paston SJ, Dennis RE, Harper JV, Dunn SM, Ashfield R, Johnson A, McGrath Y, Plesa G, June CH, Kalos M, Price DA, Vuidepot A, Williams DD, Sutton DH, Jakobsen BK. Monoclonal TCR-redirected tumor cell killing. Nat Med 2012; 18 (6): 980-987

8. Zhao Y, Bennett AD, Zheng Z, Wang QJ, Robbins PF, Yu LY, Li Y, Molloy PE, Dunn SM, Jakobsen BK, Rosenberg SA, Morgan RA. High-affinity TCRs generated by phage display provide $\mathrm{CD} 4^{+} \mathrm{T}$ cells with the ability to recognize and kill tumor cell lines. J Immunol 2007; 179(9): 5845-5854

9. Rapoport AP, Stadtmauer EA, Binder-Scholl GK, Goloubeva O, Vogl DT, Lacey SF, Badros AZ, Garfall A, Weiss B, Finklestein J, Kulikovskaya I, Sinha SK, Kronsberg S, Gupta M, Bond S, Melchiori L, Brewer JE, Bennett AD, Gerry AB, Pumphrey NJ, Williams D, Tayton-Martin HK, Ribeiro L, Holdich T, Yanovich S, Hardy N, Yared J, Kerr N, Philip S, Westphal S, Siegel DL, Levine BL, Jakobsen BK, Kalos M, June CH. NY-ESO-1-specific TCRengineered $\mathrm{T}$ cells mediate sustained antigen-specific antitumor effects in myeloma. Nat Med 2015; 21(8): 914-921

10. Robbins PF, Kassim SH, Tran TL, Crystal JS, Morgan RA, Feldman SA, Yang JC, Dudley ME, Wunderlich JR, Sherry RM, Kammula US, Hughes MS, Restifo NP, Raffeld M, Lee CC, Li YF, El-Gamil M, Rosenberg SA. A pilot trial using lymphocytes genetically engineered with an NY-ESO-1-reactive T-cell receptor: long-term follow-up and correlates with response. Clin Cancer Res 2015; 21 (5): 1019-1027
11. Schmidt-Wolf IG, Lefterova P, Mehta BA, Fernandez LP, Huhn D, Blume KG, Weissman IL, Negrin RS. Phenotypic characterization and identification of effector cells involved in tumor cell recognition of cytokine-induced killer cells. Exp Hematol 1993; 21(13): 16731679

12. Pievani A, Belussi C, Klein C, Rambaldi A, Golay J, Introna M. Enhanced killing of human B-cell lymphoma targets by combined use of cytokine-induced killer cell (CIK) cultures and anti-CD20 antibodies. Blood 2011; 117(2): 510-518

13. Mata-Molanes JJ, Sureda González M, Valenzuela Jiménez B, Martínez Navarro EM, Brugarolas Masllorens A. Cancer immunotherapy with cytokine-induced killer cells. Target Oncol 2017; 12 (3): 289-299

14. Mesiano G, Todorovic M, Gammaitoni L, Leuci V, Giraudo Diego L, Carnevale-Schianca F, Fagioli F, Piacibello W, Aglietta M, Sangiolo D. Cytokine-induced killer (CIK) cells as feasible and effective adoptive immunotherapy for the treatment of solid tumors. Expert Opin Biol Ther 2012; 12(6): 673-684

15. Schmidt-Wolf IG, Negrin RS, Kiem HP, Blume KG, Weissman IL. Use of a SCID mouse/human lymphoma model to evaluate cytokine-induced killer cells with potent antitumor cell activity. J Exp Med 1991; 174(1): 139-149

16. Todorovic M, Mesiano G, Gammaitoni L, Leuci V, Giraudo Diego L, Cammarata C, Jordaney N, Carnevale-Schianca F, Gallo S, Fagioli F, Piacibello W, Elia AR, Pignochino Y, Dell'aglio C, Grignani G, Cignetti A, Aglietta M, Sangiolo D. Ex vivo allogeneic stimulation significantly improves expansion of cytokine-induced killer cells without increasing their alloreactivity across HLA barriers. J Immunother 2012; 35(7): 579-586

17. Du SH, Li Z, Chen C, Tan WK, Chi Z, Kwang TW, Xu XH, Wang S. Co-expansion of cytokine-induced killer cells and $\mathrm{V} \gamma 9 \mathrm{~V} \delta 2 \mathrm{~T}$ cells for CAR T-cell therapy. PLoS One 2016; 11(9): e0161820

18. Gao X, Mi Y, Guo N, Xu H, Xu L, Gou X, Jin W. Cytokine-induced killer cells as pharmacological tools for cancer immunotherapy. Front Immunol 2017; 8: 774

19. Guo Y, Han W. Cytokine-induced killer (CIK) cells: from basic research to clinical translation. Chin J Cancer 2015; 34(3): 99-107

20. Hinrichs CS, Rosenberg SA. Exploiting the curative potential of adoptive T-cell therapy for cancer. Immunol Rev 2014; 257(1): 5671

21. Gure AO, Chua R, Williamson B, Gonen M, Ferrera CA, Gnjatic S, Ritter G, Simpson AJ, Chen YT, Old LJ, Altorki NK. Cancer-testis genes are coordinately expressed and are markers of poor outcome in non-small cell lung cancer. Clin Cancer Res 2005; 11(22): 80558062

22. Chen YT, Scanlan MJ, Sahin U, Türeci O, Gure AO, Tsang S, Williamson B, Stockert E, Pfreundschuh M, Old LJ. A testicular antigen aberrantly expressed in human cancers detected by autologous antibody screening. Proc Natl Acad Sci USA 1997; 94 (5): 1914-1918

23. Barrow C, Browning J, MacGregor D, Davis ID, Sturrock S, Jungbluth AA, Cebon J. Tumor antigen expression in melanoma varies according to antigen and stage. Clin Cancer Res 2006; 12(3): 764-771

24. Gnjatic S, Nishikawa H, Jungbluth AA, Güre AO, Ritter G, Jäger E, Knuth A, Chen YT, Old LJ. NY-ESO-1: review of an immunogenic tumor antigen. Adv Cancer Res 2006; 95: 1-30 
25. Robbins PF, Li YF, El-Gamil M, Zhao Y, Wargo JA, Zheng Z, Xu H, Morgan RA, Feldman SA, Johnson LA, Bennett AD, Dunn SM, Mahon TM, Jakobsen BK, Rosenberg SA. Single and dual amino acid substitutions in TCR CDRs can enhance antigen-specific T cell functions. J Immunol 2008; 180(9): 6116-6131

26. White SM, Renda M, Nam NY, Klimatcheva E, Zhu Y, Fisk J, Halterman M, Rimel BJ, Federoff H, Pandya S, Rosenblatt JD, Planelles V. Lentivirus vectors using human and simian immunodeficiency virus elements. J Virol 1999; 73(4): 2832-2840

27. Sastry L, Johnson T, Hobson MJ, Smucker B, Cornetta K. Titering lentiviral vectors: comparison of DNA, RNA and marker expression methods. Gene Ther 2002; 9(17): 1155-1162

28. Elia AR, Circosta P, Sangiolo D, Bonini C, Gammaitoni L, Mastaglio S, Genovese P, Geuna M, Avolio F, Inghirami G, Tarella C, Cignetti A. Cytokine-induced killer cells engineered with exogenous T-cell receptors directed against melanoma antigens: enhanced efficacy of effector cells endowed with a double mechanism of tumor recognition. Hum Gene Ther 2015; 26(4): 220-231

29. Tan MP, Gerry AB, Brewer JE, Melchiori L, Bridgeman JS, Bennett AD, Pumphrey NJ, Jakobsen BK, Price DA, Ladell K, Sewell AK. T cell receptor binding affinity governs the functional profile of cancer-specific $\mathrm{CD}^{+} \mathrm{T}$ cells. Clin Exp Immunol 2015; 180(2):
255-270

30. Betts MR, Brenchley JM, Price DA, De Rosa SC, Douek DC, Roederer M, Koup RA. Sensitive and viable identification of antigen-specific $\mathrm{CD}^{+} \mathrm{T}$ cells by a flow cytometric assay for degranulation. J Immunol Methods 2003; 281(1-2): 65-78

31. Pievani A, Borleri G, Pende D, Moretta L, Rambaldi A, Golay J, Introna M. Dual-functional capability of $\mathrm{CD} 3{ }^{+} \mathrm{CD} 56^{+} \mathrm{CIK}$ cells, a T-cell subset that acquires NK function and retains TCR-mediated specific cytotoxicity. Blood 2011; 118(12): 3301-3310

32. Ma Y, Xu YC, Tang L, Zhang Z, Wang J, Wang HX. Cytokineinduced killer (CIK) cell therapy for patients with hepatocellular carcinoma: efficacy and safety. Exp Hematol Oncol 2012; 1(1): 11

33. Stone JD, Chervin AS, Kranz DM. T-cell receptor binding affinities and kinetics: impact on T-cell activity and specificity. Immunology 2009; 126(2): 165-176

34. Chan WC, Linn YC. A comparison between cytokine- and beadstimulated polyclonal $\mathrm{T}$ cells: the superiority of each and their possible complementary role. Cytotechnology 2016; 68(4): 735748

35. Linn YC, Lau SK, Liu BH, Ng LH, Yong HX, Hui KM. Characterization of the recognition and functional heterogeneity exhibited by cytokine-induced killer cell subsets against acute myeloid leukaemia target cell. Immunology 2009; 126(3): 423-435 